\title{
Implementing an intended brand personality: a dyadic perspective
}

\author{
Lucia Malär • Bettina Nyffenegger - Harley Krohmer • \\ Wayne D. Hoyer
}

Received: 29 March 2010 / Accepted: 8 February 2011 / Published online: 25 February 2011

(C) Academy of Marketing Science 2011

\begin{abstract}
The authors examine the transformation of an intended brand personality (i.e., the way brand management would like consumers to perceive the brand's personality) into a realized brand personality (i.e., the consumer's actual perception of the brand's personality). Drawing on the results of a dyadic empirical cross-industry study of 137 brand managers and 3,048 consumers, the authors show that the singularity of the brand personality profile, the competitive differentiation of the brand, the credibility of brand communication, consumers' depth of product involvement, and consumers' prior brand attitude all affect the degree to which the realized brand personality resembles the intended brand personality.
\end{abstract}

Keywords Perceived brand personality · Intended brand personality. Brand strategy implementation Brand performance

The authors thank the Swiss National Science Foundation for financially supporting this research project.

L. Malär $(\varangle) \cdot$ B. Nyffenegger $\cdot$ H. Krohmer

Institute of Marketing and Management, University of Bern,

Engehaldenstrasse 4,

3012 Bern, Switzerland

e-mail: malaer@imu.unibe.ch

B. Nyffenegger

e-mail: nyffenegger@imu.unibe.ch

H. Krohmer

e-mail: krohmer@imu.unibe.ch

W. D. Hoyer

Department of Marketing, McCombs School of Business,

The University of Texas at Austin, One University Station B6700,

Austin, TX 78712-1176, USA

e-mail: wayne.hoyer@mccombs.utexas.edu
Brand personality has emerged as a key brand characteristic in the marketing academic literature (Aaker 1997; Grohmann 2009; Wentzel 2009) and in managerial practice (e.g., Aufreiter et al. 2003; Court et al. 1997) because it has implications for our understanding of brand effects as well as the firm's performance in the marketplace. Brand personality "refers to the set of human characteristics associated with a brand" (Aaker 1997, p. 347).

In marketing practice, many managers carefully define the intended brand personality and invest often extensive resources into brand-related marketing activities to ensure that consumers perceive the brand as intended (Burnett and Hutton 2007). However, such a formulation and implementation of a brand personality is often a difficult challenge, as "strong brands do not just happen. Rather, they result from the creation of winning brand strategies and brilliant executions from committed, disciplined organizations" (Aaker 1996, p. 358).

Prior research has neglected such a managerial perspective on brand personality and rather has focused on the consumer's perception of brand personality (a consumer behavior perspective). A key point, however, is that consumers may not necessarily perceive the brand personality as intended. Only with successful implementation does this occur. Therefore, we combine a managerial with a consumer perspective to focus on the implementation of an intended brand personality by comparing the intention of managers (intended brand personality) with the perception of consumers (perceived or realized brand personality). These have been referred to as the "two different faces of brand personality" (Plummer 1984/ 1985, p. 28).

Our resulting implementation perspective on brand personality builds on the seminal work of Mintzberg (1978), who distinguished between intended and realized marketing strategies. This distinction is relevant because if the intended brand personality (what consumers should 
think and feel about the brand) differs from the realized brand personality (what consumers actually do think and feel about the brand), there can be negative consequences for the brand. Because marketing implementation is so critical for performance (Bonoma 1984; Piercy 1998), a focus on this understudied topic in the brand personality literature could add to our knowledge in this area.

In our study, we employ a dyadic design (i.e., surveying both managers and consumers), which allows us to measure the success of brand personality implementation. We argue that an intended brand personality is successfully implemented if consumers perceive the brand personality in a manner similar to that intended by brand managers. We further analyze the factors that drive a successful brand personality implementation. Finally, by investigating the performance implications of a successful brand personality implementation, we highlight the managerial relevance of brand personality implementation.

\section{Literature review}

A range of conceptual and empirical studies deals with the topic of brand personality. The largest research stream focuses on the conceptualization and operationalization of this construct (e.g., Aaker 1997; Geuens et al. 2009; Grohmann 2009; Venable et al. 2005). These studies examine brand personality as perceived by consumers (i.e., realized brand personality). A main contribution of this research stream is the identification and empirical validation of various dimensions of a realized brand personality. A second category of studies examines the antecedents of realized brand personalities such as the spokesperson (Grohmann 2009), employee behavior (Wentzel 2009), brand extensions (Diamantopoulos et al. 2005), and brand experiences (Brakus et al. 2009). A third category of studies focuses on the direct performance outcomes of a perceived (realized) brand personality. These studies have found that brand personality can have positive performance implications, such as identification with the brand (e.g., Ambler 1997), brand affect and brand trust (e.g., Sung and Kim 2010), satisfaction and brand loyalty (Brakus et al. 2009), and brand relationship quality (e.g., Aaker et al. 2004; Fournier 1998). However, these studies do not examine which marketing activities support the transformation of an intended into a realized brand personality and do not take an implementation perspective that compares strategic intentions with the realization in the market place.

Despite the many studies conducted on brand personality, these research streams have left two important unanswered questions. First, how can brand managers successfully turn a specific intended brand personality into action so that consumers perceive the brand's personality as managers desire? While many firms have clear ideas of how their brand personalities should be perceived, they often fail to communicate those attributes. Failed execution, inattentive management, or too wide of a gap between the personality and the product's actual utility can all defeat a solid brand strategy. According to Triplett (1994, p. 9), "Brand personality must be managed or it will assume a life of its own." As Bonoma further notes, "it is invariably easier to think up clever marketing strategies than it is to make them work" (1984, p. 69).

Second, are brands whose personalities match marketers' intentions more successful (e.g., in terms of customer loyalty or market share) than those that do not? Despite all the research that has been conducted on brand personality, it is still unclear whether brands whose actual personalities match their marketers' aspirations are better performers than brands whose personalities have diverged from plan. Besides being theoretically interesting, the answer is highly relevant for managers and indeed is ultimately the most critical of the entire discussion.

\section{Research framework and conceptual foundations}

Our general research framework builds on basic communication models (see e.g., Katz 1957; Lasswell 1948; Shannon and Weaver 1949) that reflect the communication chain from the sender to the receiver (see Figure 1). The basic idea is that a sender (the brand manager) designs specific communications to encode his intended message (intended brand personality), which he then communicates to the receiver (consumer) who decodes (interprets) and learns the received information. The result of this process is the perceived brand personality, which is stored as an associative node in the consumer's memory (Anderson 1990; Collins and Loftus 1975). If there is a fit between the perceived and the intended brand personality, the communication strategy (intended brand personality) has been successfully implemented. A key goal of the present study is to examine the antecedents or drivers of this fit. To understand this process of consumer decoding we draw on categorization theory.

A growing body of literature points to the usefulness of categorization theory in explaining various aspects of



Fig. 1 Communication model 
consumer behavior (Alba and Hutchinson 1987; Cohen and Basu 1987; Stayman et al. 1992). Categorization theory was proposed by Rosch and her colleagues (Mervis and Rosch 1981; Rosch 1975, 1978) as an explanation of the cognitive processes underlying concept formation for natural objects. Categorization is a simplification strategy that people employ in an attempt to reduce complexity in their environment (Rosch 1978). Categorization theory has been quite useful in increasing social psychologists' understanding of how people perceive the personalities of others (Cantor and Mischel 1979; Taylor et al. 1978). Thus, it can also be useful in explaining the perception of brand personalities by consumers.

A critical assertion of this theory is that people (consumers) form cognitive categories called schemas (Barsalou 1992) based on their observations of the features or attributes of objects. Brand personality is reflected by human-like features, which become strongly associated with the brand (Aaker 1997). In our context, a consumer observes the communicated brand personality attributes and connects these attributes to the brand node in memory. The consumer uses his or her prior knowledge to label, identify, and classify the underlying brand (i.e., brand as a category; Park et al. 1991). As an example, on the basis of specific communication content a consumer may categorize a brand as one with a personality that is competent and sophisticated. Memory is much stronger and faster for such category-based processed information (Fiske and Pavelchak 1986). This is especially true when the associative links between the brand concept and the features are strong.

In order to understand how an intended brand personality can be successfully transformed into a perceived brand personality, we need to understand which factors facilitate categorization by consumers. Building on prior research on categorization theory (MacInnis and Jaworski 1989; MeyersLevy 1991; Rota and Zellner 2007; Smallman and Roese 2008; Ülkümen et al. 2010), we examine five factors that should enhance precise categorization and therefore drive the successful implementation of an intended brand personality: singularity of the brand's personality profile, perceived competitive differentiation, credibility of brand-related communication activities, consumers' product involvement, and consumers' brand attitude. These variables (with the exception of singularity) have been studied in a persuasion context (e.g., Janiszewski 1998; MacInnis et al. 1991; Meyers-Levy and Peracchio 1995); however, based on categorization theory, we introduce a fresh perspective on these variables by analyzing their role in the fit between intended and realized brand personalities.

As shown in Fig. 2, the central construct in our research framework is the fit between the intended and the realized brand personality. We conceptualize both constructs by using the multidimensional and multifaceted conceptualization developed by Aaker (1997). Similar to the "Big Five" model of human personality (Goldberg 1990), brand personality is conceptualized along five dimensions (sincerity, excitement, competence, sophistication, and ruggedness) that both consumers and managers can use to characterize the underlying brand.

In our framework, we focus on the antecedents of the fit between intended and realized brand personality that play an important role in terms of conceptual (derived from categorization theory) and managerial considerations. To learn more about relevant managerial considerations, a qualitative study of eight brand and advertising managers was conducted. In qualitative expert interviews, we asked managers to discuss factors that from their practical experience may play a prominent role in the implementation of a brand personality. Based on these discussions, managers confirmed the importance of the five proposed antecedents: singularity of the brand personality profile, competitive differentiation of the brand, credibility of brand-related communication activities, consumer's product involvement, and consumer's prior brand attitude.

Singularity of the brand personality profile refers to the focus and single-mindedness of the brand personality
Fig. 2 Conceptual framework of brand personality

implementation

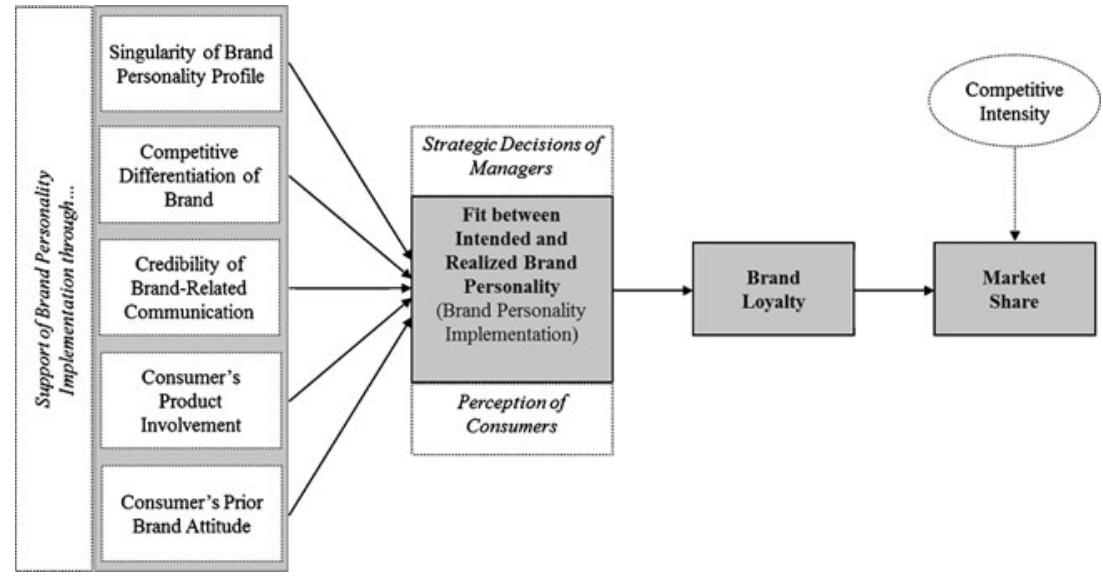


profile as intended by management. In the management literature, Ries and Ries (2002, p. 109f.) discuss the concept of singularity as an important driver of brand performance: "The most important aspect of a brand is its single-mindedness.... What's a brand? A singular idea or concept that you own inside the mind of the prospect." When managers define an intended brand personality, they determine how many brand personality dimensions should be considered and on which of these dimensions the brand should score high (or low). This definition results in an intended brand personality profile that combines all relevant personality dimensions and relates them to each other. If the various brand personality dimensions all have similarly high values, the brand personality profile is multifaceted and rather complex. In contrast, if some personality dimensions score high, while other dimensions score low, the brand personality profile is more focused, resulting in a higher degree of singularity (for an illustration of a brand's personality profile see Fig. 3). Thus, the construct of singularity is represented on a continuum ranging from low singularity (a highly complex personality profile where all personality dimensions have the same value) to high singularity (only one personality dimension has a high value, while the other personality dimensions score low). For example, Harley Davidson scores high on singularity by focusing on the brand personality dimension ruggedness (emphasis on masculinity, defiance, and rugged individualism; Fournier 2001). Abercrombie \& Fitch also established a singular brand personality, scoring high on excitement and rather low on other brand personality dimensions by stressing aspects such as spirited, young, outgoing, and sexy.

The concept of singularity has also been discussed in the management literature. According to Ries and Ries (2002), an important success factor for brands is that they own a singular idea or concept inside the mind of the consumer. The potential relevance of singularity for brand personality implementation was also illustrated in our qualitative

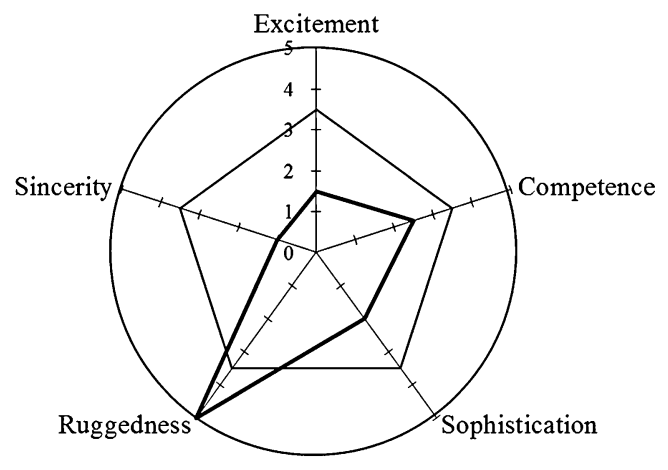

- Brand Personality Profile 1: Low Degree of Singularity

—Brand Personality Profile 2: High Degree of Singularity

Fig. 3 Brand personality profiles interviews. As an example, one brand strategy consultant complained to us: "In many workshops on brand personality with clients, my greatest challenge is to 'reduce it to the max.' Often managers from different units are involved. To reach consensus, their personal views are integrated into the brand personality. As everyone feels qualified and entitled to contribute to the brand's personality, this overloads the brand personality; too many dimensions are emphasized at the same time. In the end, such brand personalities are interchangeable and often do not leave a lasting impression among consumers."

Competitive differentiation reflects the degree to which consumers view the brand as generally distinctive from competing brands (Netemeyer et al. 2004). More specifically, it reflects the uniqueness of the brand and refers not just to the brand's personality but to the brand as a whole (including, for example, functional product attributes, product design, etc.). Examples of brands that score high on competitive brand differentiation include the Smart car by Mercedes, with its unique design and its focus on innovativeness and sustainability, and The Body Shop, which has successfully differentiated itself from competitors by building an image as a caring company that helps protect the environment and prevents the suffering of animals.

The relevance of competitive differentiation in the context of brand personality implementation is highlighted by the following statement of a brand manager from our interviews: "In the past we often were obsessed with customers' preferences during our brand-building activities. Customer-oriented branding was our credo so that in my opinion we neglected the competitors. However, based on market research, we realized that with such a focus on customers, some of our brands did not have a clear image. To be honest, some customers got confused when they were asked to report the core values of our brands and those of competitors." This quote illustrates a strong focus on customer orientation in brand positioning but a lack of competitive differentiation. Consumers were not fully aware of the differences between alternative competitive brands and, as a result, the competitive differentiation of the brands was low.

The constructs of singularity and competitive brand differentiation represent two different perspectives. Singularity is based on an internal brand perspective, reflecting the scope (focus versus complexity) of the brand personality profile. Competitive differentiation, on the other hand, represents an external brand perspective, comparing the brand to competitive brands in a general way (comparing various components of the brands such as brand personality, brand image, product design, and functionalities). Two brands may have a high degree of singularity (scoring high on only some specific brand personality dimensions) but not be perceived as different from each other (i.e., if they focus on the same personality 
dimensions and maybe even have a similar product design). As an example, H\&M and Zara are two fashion brands with a relatively singular brand personality profile, focusing on excitement (young, trendy, innovative). However, their competitive differentiation from each other is rather low, as they focus on similar brand personality characteristics and also aim at a similar product assortment and product design.

Our third antecedent, credibility of brand-related communication activities, refers to the believability of communication content. This construct reflects the extent to which a consumer believes claims made in brand-related communication activities to be truthful and believable (MacKenzie and Lutz 1989) and has been shown to have an impact on the evaluation of information by consumers (Kang and Herr 2006; Kelley 1967, 1972). As prominent examples, Whole Foods and Viagra are perceived to tell credible stories and to fulfill the promises they make in communication. The importance of credibility is illustrated in the following quote by a brand strategy consultant: "When car manufacturer $\mathrm{X}$ had technical problems with model $\mathrm{Y}$ and in advertising still emphasized its technical superiority and competence, consumers did just not buy these claims ... it was even counterproductive. I think customers then also questioned other brand promises and were really skeptical about the manufacturer's advertising."

A fourth antecedent, the consumer's product involvement, has been discussed as an important variable affecting a consumer's response to information (e.g., Burnkrant and Sawyer 1983; Celsi and Olson 1988; Mitchell 1979) and hence should affect brand personality implementation. Product involvement reflects an internal state of arousal based on the perceived relevance of a product class and on the consumer's inherent needs, interests, and values (Andrews et al. 1990; Zaichkowsky 1985) and can be either situational or enduring (Bloch and Richins 1983; Richins and Bloch 1986; Richins et al. 1992). The relevance of this variable for brand personality implementation is illustrated by a statement of a brand manager from an FMCG company: "When we develop communication strategies for new brands, one of the greatest challenges is to define the message for those customers who do not really care about our products. We invest days after days in coming up with intelligent brand personalities just to find out that with those customers often only a fraction of it gets caught in their minds." In other words, customers "that do not care" about the products are customers with a low level of product involvement who will pay less attention to brand-related communication activities (which certainly affects the implementation of an intended brand personality).

The last antecedent, the consumer's prior brand attitude, refers to a positive or negative evaluative response to a brand and is based on prior knowledge and beliefs about the brand (Petty and Cacioppo 1986). The brand attitude, which is internalized in the consumer's long-term memory, will affect his or her response to brand-related information and hence the implementation of an intended brand personality. The importance of this construct is also highlighted by the following statement of one of our respondents, the head of marketing of an airline company: "We analyzed the brand relationships and brand attitudes of customers in our frequent flyer program. It was interesting to see that those frequent flyers with a positive attitude and a strong emotional bond towards our brand seem to really know our brand well. Their image of our brand comes really close to what we envisioned for our brand."

The second part of our conceptual framework focuses on whether brands whose personalities match marketers' intentions are stronger than those that do not. This issue is addressed by examining the performance outcomes of the fit between intended and realized brand personality. Specifically, we determine whether brand loyalty, as a direct performance outcome of brand personality implementation, influences the market share of the underlying brand. By linking brand personality implementation with these performance outcomes, we can demonstrate the managerial relevance of successful brand personality implementation.

\section{Hypotheses}

A central point of our study is that an intended brand personality is successfully implemented if consumers perceive the brand personality similarly to how it was intended by brand managers. In other words, the success of a brand personality implementation is the degree to which the intentions of brand managers and the perceptions of consumers converge.

In our first hypothesis, we examine how the singularity of a brand's personality profile affects the fit between intended and realized brand personality. In the context of managers' encoding, a highly singular brand personality profile should be a simpler information cue (due to the focus on only one dimension) relative to a low-singular brand personality profile, which is based on multiple cues. When the message is less complex (emphasizing only a few brand personality dimensions), it is easier to encode the message with fewer errors (Park et al. 1986). Thus, managers will have fewer problems transferring the intended brand personality into specific brand-related activities such as advertising, sponsoring events, public relations, internal communications, and even product design. Further, in the context of consumers' categorization, a highly singular brand personality profile (which stands for one thing) can be categorized more easily and precisely (Meyvis and Janiszewski 2004). The scope for interpretation is smaller, reducing the probability of misinterpretations of brand-related 
communication and advertising (Crawford 1991; Park et al. 1986). This increases the probability that the brand personality is categorized and hence learned by recipients as intended by managers.

On the other hand, the implementation of a brand personality profile that has low singularity requires a focus on different brand personality dimensions at the same time and thus the simultaneous use of different communication content (with sometimes even conflicting information cues). For example, it is generally much harder to encode a brand personality that involves several dimensions simultaneously (such as ruggedness, sincerity, and sophistication) than one that focuses on only one dimension (such as excitement). Further, such a "broad" brand personality profile may lead each consumer to focus on a different brand personality dimension (partial information interpretation), which then leads to a less precise categorization of the brand and hence a more inconsistent perception of the brand's personality. Hence, we hypothesize:

H1: The higher the degree of singularity of a brand's personality profile, the better the fit between intended and perceived brand personality.

Our second hypothesis refers to the competitive differentiation of a brand and its impact on brand personality implementation. When competitive differentiation is high, the brand is perceived as unique in relation to other brands. Prior research has shown that unique or distinctive stimuli are more likely to get attention and be processed by consumers because they stand out in relation to competing stimuli (Carpenter et al. 1994; Carpenter and Nakamoto 1989; Janiszewski 1998; Park et al. 2006). The distinctiveness of a stimulus is also crucial to the categorization process (Hamilton 1979). More distinctive stimuli help the consumer to categorize accurately. If a brand is competitively different from others, categorizing it is easier and clearer. If brands are similar, consumers may associate the target brand with the wrong concepts or nodes or place competitive brands in incorrect categories. Hence, when there is a low level of competitive differentiation, the realized brand personality might contain elements from the core brand plus competitive brands. In other words, consumers may confuse brands positioned similarly to each other when they perceive and evaluate the corresponding communication activities. For example, consumers might confuse the brand personalities of two Japanese car manufacturer brands A and B that are both positioned as reliable "value for money" products with a similar product design and safety features. As a consequence, the perceived brand personality of brand $\mathrm{B}$ may contain elements of brand A, even though the two intended brand personalities are distinct. Thus, consumers may not be able to precisely categorize such brand-related information, thereby leading to incorrect generalizations or biases (Hamilton 1981). Such a confounding (or transfer) effect would weaken the fit between the intended and the realized brand personality. The above arguments lead us to the following hypothesis:

$\mathrm{H} 2$ : The higher the level of competitive differentiation of a brand, the better the fit between intended and perceived brand personality.

Our third hypothesis refers to the credibility of brandrelated communication activities. The credibility of the message plays an important role for the decoding of the message and the accurate categorization by consumers (MacInnis and Jaworski 1989). It has been argued that brand communication activities that are perceived as credible increase consumers' willingness to objectively interpret the information provided in brand-related communication, leading to a more accurate categorization of the brand (e.g., Hovland and Weiss 1951; Petty and Cacioppo 1986; Sternthal et al. 1978). In other words, when credibility is high, consumers tend to be less critical toward brand-related communication and accept brand messages as intended by the advertiser. Empirically, researchers have found that consumers' responses are more congruent with the intent of the advertiser if consumers perceive the ad as credible (Cotte et al. 2005). In contrast, consumers will discount a message lacking in credibility and will not be persuaded (e.g., Kang and Herr 2006; Kelley 1967, 1972; Kirmani 1990; Meyers-Levy and Peracchio 1995). Such a critical cognitive elaboration of communication messages increases the chances that the interpretation of communication content may differ from the managers' intentions. We argue that the more credible the communication, the higher the probability that consumers perceive the underlying brand personalities in ways intended by managers.

H3: The higher the perceived credibility of brand-related communication, the better the fit between intended and perceived brand personality.

The consumer's product involvement is the focus of our fourth hypothesis. It has been widely acknowledged that involvement increases consumers' motivation to actively search for and retrieve information (Petty et al. 1983). This information is also processed more intensively, with the consumer focusing on more detailed arguments (Petty and Cacioppo 1986). Further, involvement increases consumers' ability to attend to detailed aspects relevant to precise categorization (Johnson and Mervis 1997). As a consequence, consumers with high involvement should have greater ability to accurately categorize the brand's personality and to comprehend the intended message (in our context the intended brand personality; Celsi and Olson 1988). This in turn increases the fit between intended and realized brand personality. 
In contrast, less involved consumers are likely to lack the motivation to engage in the active processing of information, and messages about the brand personality may be overlooked (Andrews and Shimp 1990; Batra and Ray 1986; Park and Young 1986; Swasy and Munch 1985). Rather, consumers may be more influenced by peripheral cues such as the type or source of the message, which may not be directly related to the intended brand personality. Based on these considerations, we hypothesize:

H4: The higher the level of consumers' product involvement, the better the fit between intended and perceived brand personality.

Our fifth hypothesis relates to the consumer's prior attitude toward the brand. If a consumer has a positive attitude toward the underlying brand, this will affect his or her processing of brand-related information (Crowley and Hoyer 1994; Fazio 1989; Katz 1960) and hence lead to a more accurate categorization of the brand's personality. Prior brand attitude has been found to have a major effect on the cognitive response consumers have to a message. Specifically, during decoding, a consumer with a positive prior brand attitude will be less prone to counter-arguing with the message and will thereby be more likely to accept the message (Greenwald 1968; Kunda 1990). Further, a positive attitude toward the brand will lead to a more detailed categorization process, as people frequently contemplate, consider, and elaborate on objects that they like. This, in turn, forms the basis for categorical differentiation (Smallman and Roese 2008) and enhances the fit between intended and realized brand personality. On the other hand, a negative prior brand attitude would lead to increased counter-arguing, thereby decreasing message acceptance and producing a less accurate categorization of the brand's personality. This would result in a lower fit between intended and realized brand personality. Hence, we hypothesize:

H5: The more positive the consumers' prior brand attitude, the better the fit between intended and perceived brand personality.

Our framework also includes the performance impact of successful brand personality implementation. In highly competitive business environments, loyal consumer-brand relationships play a key role for a brand's sustainable competitive advantage (Srivastava et al. 2001). Loyal customers are a competitive asset (Dekimpe et al. 1997), representing a basis for charging price premiums and a barrier to competitive entry (Aaker 1991). We analyze brand loyalty as a central outcome variable of brand personality implementation success.

Companies often achieve customer loyalty by being highly customer focused and driven by customer demands
(Jaworski and Kohli 1993). In this context, it is assumed that brand managers would attempt to define an intended brand personality based on market research designed to appeal to customers' needs and desires. Therefore, if consumers perceive the brand personality as intended by managers, the resulting realized brand personality should be appealing to them, thereby increasing their loyalty. In support of this view, research has shown that brand personality increases levels of preference, trust, and loyalty (e.g., Fournier 1994).

In our conceptualization of brand loyalty we include both behavioral and attitudinal aspects (e.g., Aaker 1991; Oliver 1999). The behavioral perspective refers to repeated purchases of the brand, while the attitudinal perspective includes a degree of dispositional commitment in terms of some unique value associated with the brand (Chaudhuri and Holbrook 2001; Jacoby and Chestnut 1978). Based on all these considerations, we hypothesize:

H6: The better the fit of an intended brand personality with a realized brand personality, the higher the consumers' loyalty to the underlying brand.

Another important indicator of brand performance is the brand's market share, which reflects the percentage of a brand's sales compared to the sales for all brands in the product category (Chaudhuri and Holbrook 2001). In prior research it has been acknowledged that customer loyalty is a significant variable in predicting market share (Assael 1998; Baldinger and Rubinson 1996; Chaudhuri and Holbrook 2001; Jacoby and Chestnut 1978). Accordingly, we expect that:

H7: The higher consumers' brand loyalty, the higher the underlying brand's market share.

Our research framework also includes the control variable competitive intensity, which should be an antecedent of a brand's market share. In the absence of competition, a brand may always perform well (Kohli and Jaworski 1990). However, under conditions of high competition consumers have a greater range of alternative brands that can satisfy their needs (Jaworski and Kohli 1993), which may reduce the brand's performance and especially the brand's market share. Thus, competitive intensity should have a negative impact on the brand's market share.

\section{Research method}

Data sample and measures

In our study, we employed a dyadic approach, surveying both brand managers and consumers. The brands were chosen based on Interbrand rankings (e.g., Interbrand 
2006). In a first step which involved a written standardized questionnaire, 137 managers from different industries reported on the intended brand personalities of their brands and their marketing activities. We first contacted the companies of the aforementioned brands by phone in order to ensure identification of the corresponding brand managers. Then, we sent an invitation letter to managers to participate in our study. As an incentive, we offered them a marketing textbook and an individual analysis of their company's brand personality relative to their competitors. The respondent managers were all responsible for the respective brands and held the following positions: head of marketing $(29.2 \%)$, head of communications $(18.2 \%)$, brand manager (18.2\%), marketing manager (14.6\%), CEO (6.6\%), head of branding (6.6\%), head of business development (4.4\%), and head of sales $(2.2 \%)$. On average the managers had 9.5 years of job experience and had been working on responsiveness for their respective brands for 4.7 years. Our sample represented brands from the following industries: fastmoving consumer goods (39.4\%), durable consumer goods $(21.9 \%)$, services $(30.7 \%)$, and retailing $(8.0 \%)$.

In a second step, e-mail invitations were sent out to 6,943 consumers, asking them to report on the brands about which the brand managers responded in the first step. These consumers included employees of governmental institutions and of individual companies; members of consumer protection associations; individuals from the student body of a university's departments of business administration, economics, law, and medicine; and high school students. In the e-mail, we provided a direct link to a specific section of a webpage that was accessible only via the link provided in the e-mail. Three thousand forty eight $(3,048)$ consumers $(55.8 \%$ female, $44.2 \%$ male, aged between 14 and 70 years, average age 24.8) responded in an online standardized questionnaire with regard to their perceptions of one brand that had been evaluated by a brand manager in the first survey. Each respondent had to first report his or her familiarity with that brand based on two items: I am familiar with this brand and I know the products of this brand. Only if the respondent reported an overall brand familiarity of at least 3.0 ( 5 = maximum familiarity; $1=$ no familiarity $)$ was that person allowed to continue with the corresponding brand. If the brand familiarity was below 3.0, a new brand was randomly assigned. This random and interactive assignment of a brand to the consumer was a key reason we used an online questionnaire. As an incentive to participate in our study, we entered respondents' names in a lottery for over $\$ 3,000$ in prizes, including helicopter flights, ski holidays, iPods, and marketing textbooks. By applying this dyadic procedure, we obtained responses from one brand manager for each of the 137 brands (the intended perspective) and, on average, responses from 22.2 consumers on the same brand (the perceived perspective), resulting in 3,048 dyads (1 manager-1 consumer).

We sent out all initial e-mails on the same day and recorded the specific dates of responses of the individual consumers. This record enabled us to distinguish between early and late respondents. Statistical tests showed no significant differences among the responses from early (defined as the first one-third of the questionnaires received) versus late respondents (defined as the last onethird of the questionnaires received) on all of our major constructs and on key demographic variables, suggesting that non-response bias is not a problem in our consumer data (Armstrong and Overton 1977). The same procedure was used to test for non-response bias in the manager sample, and the results also suggest non-response bias is not a problem with that sample.

We also ascertained the knowledgeability of managers with a direct self-report measure. Managers scored themselves on the following item: "How knowledgeable did you feel while answering this questionnaire?" $(1=$ "not at all knowledgeable" and $5=$ "highly knowledgeable"). The mean score on this item was 4.1, thus providing evidence of respondent knowledgeability. However, we eliminated the responses from three managers who reported a knowledgeability of only 1 or 2 . To test whether managers were familiar with the concept of brand personality and whether they explicitly position their brand in terms of a specific personality, we included control questions assigned on fivepoint Likert scales anchored by "strongly disagree" and "strongly agree": "Our firm has a clear idea of what the intended brand personality of brand X should look like" (Mean=4.61, SD=.61), "Our firm has a clear idea about which concrete personality traits brand X should have" (Mean=4.55, $\mathrm{SD}=.70$ ), and "Our intended brand personality is written down or formulated in terms of concrete personality traits" (Mean=3.82, $\mathrm{SD}=1.22)$. The high mean values show that managers are knowledgeable about the concept of brand personality.

Measurement of independent variables The scales used in our study were largely based on empirically validated scales from prior studies (for an overview of our measurement scales and the individual items, see the Appendix). With one exception (the brand's market share), all items were measured with five-point Likert scales anchored by "strongly disagree" and "strongly agree." We pre-tested our questionnaire and further refined it on the basis of the comments of 50 master of business administration students.

The singularity of an intended brand personality profile reflects the relative variability or dispersion of the different brand personality dimensions within a brand. A commonly 
used statistical measure of dispersion is the coefficient of variation $(\mathrm{CV})$, which is defined as the ratio of the standard deviation (SD) to the mean (e.g., Hendricks and Robey 1936):

$\mathrm{CV}=\frac{S D}{\bar{x}} ; \quad \mathrm{SD}=\sqrt{\frac{\sum_{x=i}^{I}\left(x_{i}-\bar{x}\right)^{2}}{n-1}}$

where $\mathrm{x}_{\mathrm{i}}$ stands for the specific brand personality dimension and $\bar{x}$ for the mean across all brand personality dimensions. A greater $\mathrm{CV}$ value indicates a greater variability (or smaller consistency) of the brand personality dimensions. Thus, a brand with a high CV value shows a singular brand personality profile. To illustrate, a brand with an extremely singular profile, where only one personality dimension scores very high and the other dimensions score very low (e.g., competence: 5.0; excitement: 1.0; sophistication: 1.0; sincerity: 1.0), shows a CV value of 1 , whereas an extremely low singular profile (e.g., all brand personality dimensions have the same scores) would show a CV value of 0 .

Our research model includes the following additional consumer-based independent variables: perceived differentiation of a brand from competitors' brands ( 3 items based on Netemeyer et al. 2004), credibility of brand-related communication (3 items based on Putrevu and Lord 1994), product involvement (3 items based on van Trijp et al. 1996), and prior attitude toward the underlying brand (4 items based on Putrevu and Lord 1994).

Measurement of dependent variables For the assessment of the realized and intended brand personality, we relied on the operationalization of Aaker (1997), who stated that brand personality comprises the dimensions of sincerity, excitement, competence, sophistication, and ruggedness. We asked subjects to think of the brand as if it were a person and to indicate on a five-point Likert scale the extent to which the personality traits describe the brand $(1=$ "not at all descriptive" and $5=$ "extremely descriptive"). In the course of our measurement validation, however, we could not confirm the dimension "ruggedness" and thus eliminated it (see also Aaker et al. 2001). The measurement evaluation process in the managers' sample and the consumers' sample revealed an operationalization of brand personality along four dimensions, which are represented by 10 facets and measured with overall 23 items.

To operationalize the fit between intended and realized brand personality (i.e., success of brand personality implementation), we used an absolute measurement term. For each consumer, the absolute distance between the intended brand personality (intended by brand manager) and the realized brand personality (perceived by consumer) was calculated at the dimensional level:

$\mathrm{d}=(-1)^{*} \sum_{i=1}^{I}\left|I B P_{i}-R B P_{i}\right|$

where IBP represents the intended brand personality, RBP refers to the realized brand personality evaluated by the consumer, and $\mathrm{i}(\mathrm{i}=1, \ldots, \mathrm{I})$ refers to the corresponding brand personality dimension (i.e., sincerity, excitement, competence, and sophistication). The multiplication by $(-1)$ ensures that high values of the new variable "fit between intended and realized brand personality" correspond to a high implementation success.

The dependent variable brand loyalty was measured in terms of agreement with two statements constructed to reflect the consumer's relative loyalty to the underlying brand compared to other brands in the product category. The two measures are inspired by loyalty measures from Aaker et al. (2004) as well as Baumgartner and Steenkamp (2006). Finally, we assessed the brand's market share with the following question: "What is the brand's market share (\%)?" The control variable competitive intensity was measured with three items based on Song and Parry (1997). A complete list of items is included in the Appendix.

\section{Measurement validation}

Before testing our hypotheses, we assessed measure reliability and validity of our constructs by running confirmatory factor analyses. The psychometric properties for all constructs are reported in the Appendix. Results indicated that the shared variances (i.e., composite reliability; Fornell and Larcker 1981) among the set of items used to measure the underlying constructs of our study all showed satisfactory values. In general, a composite reliability of at least .6 is considered desirable (Bagozzi and Yi 1988). As shown in the Appendix, each measure met this criterion. Additionally, almost all coefficient alpha values exceeded the threshold value of .7 recommended by Nunnally (1978), suggesting a reasonable degree of internal consistency between the corresponding indicators. This conclusion is supported by the fact that all the factor loadings were significant $(p<.01)$, which has been suggested as a criterion of convergent validity by Bagozzi et al. (1991). Finally, we assessed the discriminant validity of the construct measures based on the criterion that Fornell and Larcker (1981) propose (i.e., discriminant validity is supported if the average variance extracted exceeds the squared correlations between all pairs of constructs). The results indicate that there are no 
problems with respect to discriminant validity. Table 1 presents the correlations between the variables in our model.

\section{Results}

We employed AMOS 17.0 to model the structural relationships posited by our conceptual framework (see Figure 2). The measures of overall fit all meet conventional standards in our structural equation model $\left(\chi^{2}(236)=2353.01\right.$, $\mathrm{RMSEA}=.05, \mathrm{SRMR}=.06, \mathrm{GFI}=.94, \mathrm{AGFI}=.92, \mathrm{NFI}=.93$, $\mathrm{NNFI}=.93$, and $\mathrm{CFI}=.94)$, which suggests that our model fits the data well (e.g., Bagozzi and Yi 1988; Bentler 1990; Browne and Cudeck 1993; Hu and Bentler 1999). We also calculated the explained variances for the endogenous variables (see Figure 4). Our antecedents explain $68 \%$ of successful brand personality implementation. The explained variance for brand loyalty is $35 \%$ and for market share $27 \%$.

In Figure 4, we report the parameter estimates of our model. The results provide empirical evidence for the hypothesized impact of $\mathrm{H} 1$, the singularity of the brand personality profile $(\gamma=.15 ; p<.01), \mathrm{H} 2$, the competitive differentiation of the brand $(\gamma=.24 ; p<.01)$, and H3, the credibility of brand-related communication activities $(\gamma=.20$; $p<.01$ ), on the implementation of an intended brand personality (i.e., fit between intended and realized brand personality). Thus, $\mathrm{H} 1$ to $\mathrm{H} 3$ can be supported. Further, product involvement has a significant positive impact on the fit between the intended and the realized brand personality $(\gamma=.30 ; p<.01)$, and a positive attitude toward the brand is also significantly related to this fit and hence brand personality implementation $(\gamma=.31 ; p<.01)$, thereby supporting $\mathrm{H} 4$ and $\mathrm{H} 5$.

As argued earlier, the success of implementing an intended brand personality (the fit between intended and realized brand personality) should enhance consumers' loyalty to the respective brand. The path coefficient from brand personality implementation success on brand loyalty is positive and significant $(\beta=.59 ; p<.01)$. Thus, H6 can be supported. Brand loyalty, in turn, positively affects the brand's market share $(\beta=.14 ; p<.01)$, supporting H7. Furthermore, market share is negatively affected by the control variable competitive intensity $(\gamma=-.50 ; p<.01)$.

Additional analysis on market share

As reported earlier, we relied on a subjective measure of market share (i.e., managers had to indicate the percentage of their brand's market share) because objective market share data were not available for a majority of the sampled firms. However, we were able to obtain this information for a subset of the brands (46). For this subsample, we correlated objective market share data with our subjective market share measure. Results revealed a highly significant correlation of .83 between our subjective market shares and the objective market shares, indicating that our subjective measure of market share reflects the brands' actual market share fairly accurately.

\section{Discussion}

In this study, we examined the antecedents of the successful implementation of intended brand personalities in terms of the fit between the intended (firm's perspective) and realized (consumers' perspective) brand personality. We empirically confirmed the following antecedents as having an important influence on fit: singularity of the brand's personality profile, competitive differentiation of the brand, credibility of brandrelated communication activities, product involvement, and prior brand attitude. Furthermore, we were able to show that the congruence between intended brand personality and realized brand personality has positive performance implications (increased brand loyalty and finally increased market share of the brand). Hence, we also provide support for the goal of our second research question - to determine whether

Table 1 Brand personality measurement scale and psychometric properties

\begin{tabular}{|c|c|c|c|c|c|c|c|c|c|c|c|}
\hline Variables & Mean & $\mathrm{SD}$ & 1 & 2 & 3 & 4 & 5 & 6 & 7 & 8 & 9 \\
\hline 1. Singularity of Brand Personality Profile & .29 & .12 & & & & & & & & & \\
\hline 2. Competitive Differentiation of Brand & 2.67 & 1.00 & $-.04 *$ & & & & & & & & \\
\hline 3. Credibility of Brand-Related Communication & 3.18 & .78 & .02 & $.38 * *$ & & & & & & & \\
\hline 4. Consumers' Product Involvement & 2.31 & 1.01 & -.02 & $.37 * *$ & $.46^{* *}$ & & & & & & \\
\hline 5. Consumers' Prior Brand Attitude & 3.32 & .86 & -.03 & $.46^{* *}$ & $.58 * *$ & $.54 * *$ & & & & & \\
\hline 6. Fit between Intended \& Realized Brand Personality & -4.06 & 1.96 & $.14 * *$ & $.36^{* *}$ & $.49 * *$ & $.47 * *$ & $.49 * *$ & & & & \\
\hline 7. Brand Loyalty & 1.90 & .95 & .01 & $.52 * *$ & $.35^{* *}$ & $.48 * *$ & $.52 * *$ & $.27 * *$ & & & \\
\hline 8. Market Share & 29.43 & 20.32 & $.09 * *$ & $.10 * *$ & $.09 * *$ & $.12 * *$ & $.10 * *$ & $.04 *$ & $.18^{* *}$ & & \\
\hline 9. Competitive Intensity & 3.65 & 1.02 & $-.16^{* *}$ & -.03 & $-.05^{*}$ & .01 & $-.10 * *$ & $.07 * *$ & $-.10 * *$ & $-.51 * *$ & \\
\hline
\end{tabular}

$* p<.05 ; * * p<.01$ 
Fig. 4 Results of the basic model

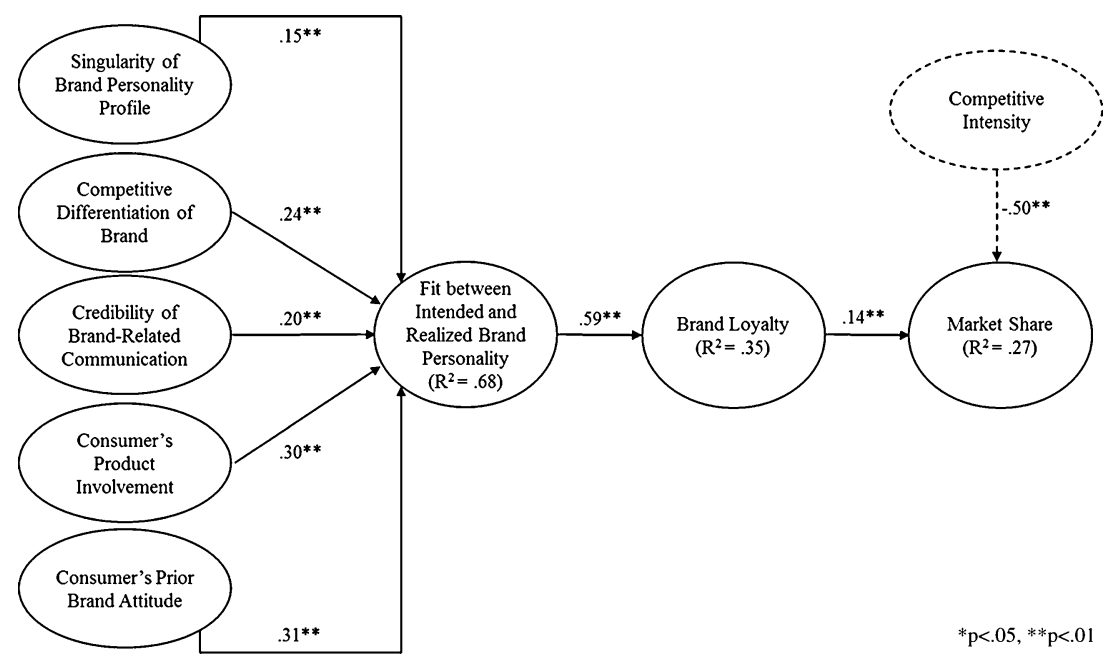

brands whose personalities match the intentions of managers are more successful than those that do not.

Academic implications

Our study provides several key contributions to the literature on brand personality. First, we introduce a new perspective for examining this construct. As mentioned earlier, prior research has mainly focused on brand personality as perceived by consumers (i.e., realized brand personality; Aaker 1997; Grohmann 2009; Wentzel 2009). Our study extends this approach by also examining the strategic intentions of managers with regard to their brand's personality. Using a dyadic approach, we compared the intended with the realized brand personality and by doing so adopted an implementation perspective on brand personality. While previous studies have provided knowledge on how to build brands in general (e.g., Ataman et al. 2008), our study generates more specific knowledge on how to successfully implement an intended brand personality. Furthermore, since we show that the successful implementation of an intended brand personality has important positive performance implications for the firm, our study supports the relevance of such an implementation perspective (see also Noble and Mokwa 1999).

Second, we identified key antecedents of successful brand personality implementation. For example, we were able to show that the singularity of an intended brand personality facilitates brand personality implementation. This underlines the importance of the complexity or simplicity of strategic intentions for strategy implementation research (Lumpkin and Dess 1995).

Furthermore, by examining the singularity of a brand's personality profile, we introduce a new perspective on brand personality. While prior research has examined the individual dimensions of brand personality and argued that these different dimensions have different antecedents and performance implications (e.g., Sung and Kim 2010), we adopted a different approach. By analyzing multiple brand personality dimensions simultaneously rather than individually, we examined the various brand personality dimensions in relation to each other (i.e., in terms of singularity of brand personality profiles). More specifically, our results show that the combination of dimensions in a personality profile is relevant: a singular brand personality profile (e.g., combination of one personality dimension with a high value and the other dimensions with rather low values) can enhance the success of brand personality implementation and as a consequence the brand's performance (market share). Thus, we were able to generate new insights that reflect the role of the structure of the brand personality profile for brand personality implementation.

We also find that the competitive differentiation of a brand facilitates brand personality implementation. This is in line with prior research on the benefits of competitive brand positioning (e.g., Keller 1993). We expand this view to the context of brand personality implementation based on categorization considerations. While prior research argues that a brand personality helps a firm to differentiate itself from its competitors, our empirical results show that a differentiated brand also facilitates the implementation of an intended brand personality. One possible explanation is that competitive differentiation makes it easier for consumers to categorize the decoded brand personality. As a consequence, there should be fewer confounding effects where consumers confuse the brand personalities of different competitive brands. Such confounding effects would weaken the fit between an intended and a realized brand personality.

The credibility of brand-related communication activities is a third success factor of brand personality implementation. We transferred the concept of credibility, which has been widely examined in a persuasion context (e.g., Kelley 1967, 1972), to the brand personality literature. Our findings highlight the importance of credibility in a brand 
personality implementation context. Therefore, a closer look at credibility of brand-related communication activities is needed. A key question would be how to achieve credibility in communications designed to implement a brand personality. This question is not a trivial one because credibility is highly subjective and consumers tend to be skeptical about marketing communication, exhibiting a tendency toward disbelief of ad claims (Obermiller and Spangenberg 1998).

Finally, the consumer's product involvement and prior brand attitude facilitate the implementation of an intended brand personality. Including consumer-related variables such as product involvement and attitudes as determinants provides a new perspective on brand personality implementation. In other words, traditional implementation research focuses primarily on managers' activities. Our inclusion of the product involvement and prior attitude variables represents a boundary-spanning perspective whereby the cognitive efforts of both the internal (managers) and external (consumers) actors play a role for successful implementation. Such a perspective is especially relevant for brand strategy implementation because in branding, the perception and evaluation by external actors (consumers) finally rule strategy implementation.

\section{Managerial implications}

Our findings show that achieving a fit between intended and realized brand personality tends to produce successful brands. In our qualitative interviews, brand managers commented that far too often their intended brand personality "gets lost in translation." In our empirical study, we found that in many cases, consumers did not perceive the brand's personality as it was intended by managers. On average, the perceived brand personality differed from the intended brand personality by 4.06 (with 0 no discrepancy and 16 full discrepancy). This suggests that the ease of both encoding (by the manager) and decoding (by the consumer) of an intended brand personality is crucial for implementation. Against this background and in light of the fact that in our study a successfully implemented brand personality was able to increase consumers' loyalty and the brand's market share, investing considerable management resources into brand personality implementation seems to be worthwhile. In addition, it would be important to monitor the discrepancy between the intention and realization of brand personality through market research to ensure that their intended brand personality does not differ too much from consumers' perception.

Further, we were able to explain $68 \%$ of the fit between intended and realized brand personality with our set of antecedents. In comparing the strength of effects of the various antecedents, there appear to be several factors that influence the fit rather than a single most prominent factor.
In other words, brand personality implementation is a complex task where managers need to account for a variety of factors. In our study, we were able to identify specific success factors of brand personality implementation on which managers need to focus.

In business practice, marketers faced with heterogeneous consumer segments have traditionally defined a brand personality in a fairly broad way, leaving enough room for the same brand to mean different things to different consumers. However, such an approach runs some risks. Consumers may, for example, perceive the brand as vague without a clear profile (Aaker and Shansby 1982). Our results indicate that making the brand personality more specific and simplistic (singular brand personality profile) can pay off in terms of implementation. A brand with a singular personality scores high on only one or at most a few brand personality dimensions while it scores lower on the other personality dimensions. Such a brand personality profile and its corresponding communication activities will be more easily processed, and this increases the probability that consumers will perceive the brand personality as intended by managers. In addition, our results also indicate that competitive differentiation and message credibility are key factors to consider as well.

Further, while the involvement and brand attitude of consumers cannot be fully controlled by managers, special attention should be paid to highly involved consumers with positive brand attitudes in brand personality implementation efforts. These consumer segments can serve as a "fan base" that managers need to fully understand and pay special attention to in order to create successful brands (Ragas and Bueno 2002). Hence, managers should find out who these customers are, what they want and like about the brand, and then try to target and develop a brand personality which is appealing to them to build deeper emotional connections with the brand.

Finally, our findings are also relevant for the topic of co-creation (Allen et al. 2008). The idea of co-creation of brand personalities by consumers and managers corresponds to the emerging trend of consumer integration in marketing activities in a Web 2.0 environment (Riegner 2007). Such an empowerment may certainly affect the implementation of intended brand personalities. In such an environment, the manager is not the only actor who defines and implements an intended brand personality. Consumers do not simply record the word, but they also create it (Escalas 2004). Thus, empowered consumers even have a say in brand strategy formulation (bringing in their brand personality expectations), which affects brand personality implementation. In particular, based on our research we can say that consumers with high involvement and a positive brand attitude would be prime candidates for this kind of activity. 
Limitations and future research

Our research is certainly not without its limitations. First, we did not consider process aspects of brand personality implementation (e.g., how it is to be developed, how consumers categorize brand personality, and how consumers actually process the communication activities referring to the brand and its intended personality). Future research could examine process variables of brand personality implementation such as the interaction between brand manager and advertising agency in developing brand communication activities, internal processes of developing strategic consensus with regard to the brand personality and communication efforts, cross-functional coordination of communication activities, as well as the actual information processing by consumers.

Second, while we focused on direct antecedents of brand personality implementation, future research could analyze whether these effects increase or decrease when adding moderating variables. These include the context of consumption (social vs. private), advertising intensity, the heterogeneity of targeted consumers, the brand loyalty of consumers, and the product category.
Third, since we investigated different product categories and assumed that brand personality always plays an important role, future research should determine whether brands matter at all in these categories. The conditions for successful brand building may not be equally favorable across categories. Brands need to be relevant to the customer in order to increase performance. This relevance has been shown to differ among product categories (Fischer et al. 2010). Hence, if brands do not matter in these categories neither will their personality.

Finally, we analyzed the singularity of an intended brand personality as a key antecedent of brand personality implementation performance. By doing so we examined the internal heterogeneity of the brand personality profile reflecting the degree of focus when defining an intended brand personality profile. Here, we did not analyze the cohesiveness of the content of the brand personality profile (i.e., how well do the brand personality characteristics fit to each other?). Such content-related cohesiveness (see also Berthon et al. 2009) could also play an important role as an antecedent of brand personality implementation performance.

\section{Appendix}

Table 2 Brand personality measurement scale and psychometric properties

\begin{tabular}{|c|c|c|c|c|c|}
\hline Facets and items & Factor loading & $t$-value & Coefficient alpha & Composite reliability & Average variance extracted \\
\hline \multicolumn{6}{|c|}{$\chi 2(214)=4520.756, \mathrm{RMSEA}=.08, \mathrm{SRMR}=.09, \mathrm{GFI}=.88, \mathrm{AGFI}=.85, \mathrm{NFI}=.90, \mathrm{NNFI}=.88, \mathrm{CFI}=.90$} \\
\hline \multicolumn{6}{|c|}{$\begin{array}{l}\text { Introductory text: We would like you to think of the brand as if it were a person. This may sound unusual, but think of the set of human } \\
\text { characteristics associated with the brand. For example, you might think that the human characteristics associated with Coke are non-conforming } \\
\text { fun, interesting, exciting and off-beat. We're interested in finding out which personality traits or human characteristics come to your mind wher } \\
\text { you think of brand X. Please indicate to what extent the following characteristics describe the brand: }\end{array}$} \\
\hline Sincerity & & & .82 & .75 & .61 \\
\hline Down-to-earth & 670 & 26.885 & .66 & .67 & .50 \\
\hline - down-to-earth & $.771^{\mathrm{a}}$ & - & & & \\
\hline - family oriented & .643 & 22.988 & & & \\
\hline Honest & .877 & 37.890 & .91 & .92 & .79 \\
\hline - honest & $.951^{\mathrm{a}}$ & - & & & \\
\hline - sincere & .941 & 95.805 & & & \\
\hline - real & .757 & 58.283 & & & \\
\hline Excitement & & & .87 & .87 & .69 \\
\hline Daring & .843 & 46.495 & .79 & .80 & .67 \\
\hline - daring & .731 & 40.363 & & & \\
\hline - exciting & $.902^{\mathrm{a}}$ & - & & & \\
\hline Spirited & .888 & 47.209 & .82 & .82 & .69 \\
\hline - spirited & $.871^{\mathrm{a}}$ & - & & & \\
\hline - young & .794 & 46.342 & & & \\
\hline Up-to-date & .756 & 42.922 & .86 & .87 & .77 \\
\hline - up-to-date & $.952^{\mathrm{a}}$ & - & & & \\
\hline - contemporary & .799 & 46.763 & & & \\
\hline
\end{tabular}


Table 2 (continued)

\begin{tabular}{|c|c|c|c|c|c|}
\hline Facets and items & Factor loading & $t$-value & Coefficient alpha & Composite reliability & Average variance extracted \\
\hline Competence & & & .88 & .91 & .78 \\
\hline Reliable & .801 & 43.098 & .80 & .82 & .69 \\
\hline - reliable & .808 & 43.647 & & & \\
\hline - secure & $.852^{\mathrm{a}}$ & - & & & \\
\hline Intelligent & .887 & 40.349 & .77 & .77 & .63 \\
\hline - intelligent & .827 & 41.503 & & & \\
\hline - corporate & $.756^{\mathrm{a}}$ & - & & & \\
\hline Successful & .950 & 43.299 & .80 & .80 & .57 \\
\hline - successful & $.751^{\mathrm{a}}$ & - & & & \\
\hline - leader & .761 & 41.098 & & & \\
\hline - confident & .746 & 40.311 & & & \\
\hline Sophistication & & & .80 & .69 & .54 \\
\hline Upper class & .860 & 36.164 & .83 & .83 & .71 \\
\hline - upper class & .790 & 40.185 & & & \\
\hline - glamorous & $.896^{\mathrm{a}}$ & - & & & \\
\hline Charming & .583 & 25.165 & .82 & .82 & .60 \\
\hline - charming & .830 & 39.812 & & & \\
\hline - feminine & .749 & 38.060 & & & \\
\hline - smooth & $.747^{\mathrm{a}}$ & - & & & \\
\hline
\end{tabular}

${ }^{\mathrm{a}}$ Item was fixed to 1 to set the scale

Table 3 Other measurement scales and psychometric properties

\begin{tabular}{lll}
\hline Managers constructs and items & $\begin{array}{l}\text { Factor } \\
\text { loading }\end{array}$
\end{tabular}$\quad \begin{aligned} & \text {-value } \\
& \begin{array}{l}\text { Coefficient } \\
\text { alpha }\end{array}\end{aligned} \begin{aligned} & \begin{array}{l}\text { Composite } \\
\text { reliability }\end{array} \\
& \begin{array}{l}\text { Average variance } \\
\text { extracted }\end{array}\end{aligned}$

$\chi 2(80)=647.21, \mathrm{RMSEA}=.05, \mathrm{SRMR}=.04, \mathrm{GFI}=.97, \mathrm{AGFI}=.96, \mathrm{NFI}=.98, \mathrm{NNFI}=.97, \mathrm{CFI}=.98$

Competitive Differentiation of the Brand

- X really stands out from other brands of (product category).

$.681^{\mathrm{a}} \quad-$

$\begin{array}{llll}\text { - I perceive X as being fundamentally different from competing brands. } & .808 & 39.919\end{array}$

- $\mathrm{X}$ is unique from other brands of (product category).

Credibility of Brand-Related Communication Activities

.908

- The claims in the ads of brand $\mathrm{X}$ are true.

- Brand-related communication activities of $\mathrm{X}$ are credible.

- I think brand-related communication activities of $\mathrm{X}$ are honest.

Product Involvement

- I have a compulsive need to know more about (product).

- Compared to other products, (product) is important to me.

- I'm interested in this (product).

Prior Brand Attitude

- I have a favorable opinion of X.

- Buying $X$ is a good decision.

- I like X.

- I think X has a lot of beneficial characteristics.

Brand Loyalty

- I am so happy with X that I no longer feel the need to watch out for other alternatives.

.89

$.783^{\mathrm{a}} \quad-$

$.889 \quad 53.069$

$.897 \quad 53.428$

$.679^{\mathrm{a}} \quad-$

$.847 \quad 40.244$

$.899 \quad 40.984$

.88

.89

.67

$.841^{\mathrm{a}} \quad-$

$.847 \quad 56.653$

$.894 \quad 61.012$

.669

40.494

$\begin{array}{lll}.79 & .79 & .66\end{array}$


Table 3 (continued)

\begin{tabular}{|c|c|c|c|c|c|}
\hline Managers constructs and items & $\begin{array}{l}\text { Factor } \\
\text { loading }\end{array}$ & $t$-value & $\begin{array}{l}\text { Coefficient } \\
\text { alpha }\end{array}$ & $\begin{array}{l}\text { Composite } \\
\text { reliability }\end{array}$ & $\begin{array}{l}\text { Average variance } \\
\text { extracted }\end{array}$ \\
\hline $\begin{array}{l}\text { - Even though the product is available in a number of different } \\
\text { brands, I always tend to buy X. }\end{array}$ & .833 & 33.332 & & & \\
\hline Competitive Intensity & & & .79 & .80 & .58 \\
\hline - There is high advertising pressure in the market of brand $\mathrm{X}$. & $.630^{\mathrm{a}}$ & - & & & \\
\hline - There are many competitors advertising in the market of brand $\mathrm{X}$. & .880 & 6.584 & & & \\
\hline - There are several strong brands in the market of brand $\mathrm{X}$. & .760 & 6.837 & & & \\
\hline
\end{tabular}

Market Share

Market share was assessed using one item: What is the brand's market share (\%)?

${ }^{\mathrm{a}}$ Item was fixed to 1 to set the scale

\section{References}

Aaker, D. A. (1991). Managing brand equity: Capitalizing on the value of a brand name. New York: The Free.

Aaker, D. A. (1996). Building strong brands. New York: The Free.

Aaker, J. L. (1997). Dimensions of brand personality. Journal of Marketing Research, 34, 347-356.

Aaker, D. A., \& Shansby, J. G. (1982). Positioning your product. Business Horizons, 25, 56-62.

Aaker, J. L., Benet-Martínez, V., \& Garolera, J. (2001). Consumption symbols as carriers of culture: a study of Japanese and Spanish brand personality constructs. Journal of Personality and Social Psychology, 81, 492-508.

Aaker, J. L., Fournier, S., \& Brasel, S. A. (2004). When good brands do bad. Journal of Consumer Research, 31, 1-16.

Alba, J. W., \& Hutchinson, J. W. (1987). Dimensions of consumer expertise. Journal of Consumer Research, 13, 411-454.

Allen, C. T., Fournier, S., \& Miller, F. (2008). Brands and their meaning makers. In C. P. Haugtvedt, P. M. Herr, \& F. R. Kardes (Eds.), Handbook of consumer psychology (pp. 781-822). New York: Psychology.

Ambler, T. (1997). Do brands benefit consumers? International Journal of Advertising, 16, 167-198.

Anderson, J. R. (1990). Cognitive psychology and its implications. New York: W.H. Freeman.

Andrews, J. C., \& Shimp, T. A. (1990). Effects of involvement, argument strength, and source characteristics on central and peripheral processing of advertising. Psychology \& Marketing, 7, 195-214.

Andrews, J. C., Durvasula, S., \& Akhter, S. H. (1990). A framework for conceptualizing and measuring the involvement construct in advertising research. Journal of Advertising, 19, 27-40.

Armstrong, J. S., \& Overton, T. S. (1977). Estimating nonresponse bias in mail surveys. Journal of Marketing Research, 14, 396-402.

Assael, H. (1998). Consumer behavior and marketing action. Cincinnati: South-Western College.

Ataman, M. B., Mela, C. F., \& van Heerde, H. J. (2008). Building brands. Marketing Science, 27, 1036-1054.

Aufreiter, N. A., Elzinga, D., \& Gordon, J. W. (2003). Better branding. McKinsey Quarterly, 4, 28-39.

Bagozzi, R. P., \& Yi, Y. (1988). On the evaluation of structural equation models. Journal of the Academy of Marketing Science, 16, 74-94.

Bagozzi, R. P., Yi, Y., \& Phillips, L. W. (1991). Assessing construct validity in organizational research. Administrative Science Quarterly, $36,421-458$.
Baldinger, A. L., \& Rubinson, J. (1996). Brand loyalty: The link between attitude and behavior. Journal of Advertising Research, $36,22-34$

Barsalou, L. W. (1992). Cognitive psychology: an overview. Hillsdale: Lawrence Erlbaum.

Batra, R., \& Ray, M. L. (1986). Situational effects of advertising repetition: the moderating influence of motivation, ability, and opportunity to respond. Journal of Consumer Research, 12, 432-445.

Baumgartner, H., \& Steenkamp, J.-B. E. M. (2006). An extended paradigm for measurement analysis of marketing constructs applicable to panel data. Journal of Marketing Research, 43, 431-442.

Bentler, P. M. (1990). Comparative fit indexes in structural models. Psychological Bulletin, 107, 238-246.

Berthon, P., Pitt, L. F., \& Campbell, C. (2009). Does brand meaning exist in similarity or singularity? Journal of Business Research, 62, 356-361.

Bloch, P. H., \& Richins, M. L. (1983). A theoretical model for the study of product importance perceptions. Journal of Marketing, 47, 69-81.

Bonoma, T. V. (1984). Making your marketing strategy work. Harvard Business Review, 62, 69-76.

Brakus, J. J., Schmitt, B. H., \& Zarantonello, L. (2009). Brand experience: what is it? How is it measured? Does it affect loyalty? Journal of Marketing, 73, 52-68.

Browne, M. W., \& Cudeck, R. (1993). Alternative ways of assessing model fit. In K. A. Bollen \& J. S. Long (Eds.), Testing structural equation models (pp. 136-162). Newbury Park: Sage.

Burnett, J., \& Hutton, R. B. (2007). New consumers need new brands. Journal of Product \& Brand Management, 16, 342-347.

Burnkrant, R. E., \& Sawyer, A. G. (1983). Effects of involvement and message content on information-processing intensity. In R. J. Harris (Ed.), Information processing research in advertising (pp. 43-64). Hillsdale: Lawrence Erlbaum Associates.

Cantor, N., \& Mischel, W. (1979). Prototypes in person perception. In L. Berkowitz (Ed.), Advances in experimental social psychology (pp. 3-52). New York: Academic.

Carpenter, G. S., \& Nakamoto, K. (1989). Consumer preference formation and pioneering advantage. Journal of Marketing Research, 26, 285-298.

Carpenter, G. S., Glazer, R., \& Nakamoto, K. (1994). Meaningful brands from meaningless differentiation: the dependence on irrelevant attributes. Journal of Marketing Research, 31, 339-350.

Celsi, R. L., \& Olson, J. C. (1988). The role of involvement in attention and comprehension processes. Journal of Consumer Research, 15, 210-224.

Chaudhuri, A., \& Holbrook, M. B. (2001). The chain of effects from brand trust and brand affect to brand performance: the role of brand loyalty. Journal of Marketing, 65, 81-93. 
Cohen, J. B., \& Basu, K. (1987). Alternative models of categorization: toward a contingent processing framework. Journal of Consumer Research, 13(4), 455-473.

Collins, A. M., \& Loftus, E. F. (1975). A spreading activation theory of semantic processing. Psychological Review, 82, 407-428.

Cotte, J., Coulter, R. A., \& Moore, M. (2005). Enhancing or disrupting guilt: the role of ad credibility and perceived manipulative intent. Journal of Business Research, 58, 361-368.

Court, D. C., Freeling, A., Leiter, M., \& Parsons, A. J. (1997). If Nike can "just do it", why can't we? McKinsey Quarterly, 3, 24-34.

Crawford, J. D. (1991). Intelligence, task complexity, and the distinction between automatic and effortful mental processing. In H. A. H. Rowe (Ed.), Intelligence: Reconceptualization and measurement (pp. 119-144). Hillsdale: Lawrence Erlbaum Associates.

Crowley, A. E., \& Hoyer, W. D. (1994). An integrative framework for understanding two-sided persuasion. Journal of Consumer Research, 20, 561-574.

Dekimpe, M. G., Steenkamp, J.-B. E. M., Mellens, M., \& Abeele, P. V. (1997). Decline and variability in brand loyalty. International Journal of Research in Marketing, 14, 405-420.

Diamantopoulos, A., Smith, G., \& Grime, I. (2005). The impact of brand extensions on brand personality: Experimental evidence. European Journal of Marketing, 39, 129-149.

Escalas, J. E. (2004). Narrative processing: Building consumer connections to brands. Journal of Consumer Psychology, 14, $168-180$.

Fazio, R. H. (1989). On the power and functionality of attitudes: the role of attitude accessibility. In A. R. Pratkanis, S. J. Breckler, \& A. G. Greenwald (Eds.), Attitude structure and function (pp. 153-179). Hillsdale: Lawrence Erlbaum Associates, Inc.

Fischer, M., Voelckner, F., \& Sattler, H. (2010). How important are brands? A cross-category, cross-country study. Journal of Marketing Research, 47, 823-839.

Fiske, S. T., \& Pavelchak, M. L. (1986). Category-based versus piecemeal-based affective responses: Developments in schematriggered affect. In R. M. Sorrentino \& T. E. Higgins (Eds.), Handbook of social cognition: Foundations of social behavior (pp. 167-203). New York: Wiley.

Fornell, C., \& Larcker, D. F. (1981). Evaluating structural equation models with unobservable variables and measurement error. Journal of Marketing Research, 18, 39-50.

Fournier, S. (1994). A consumer-brand relationship framework for strategic brand management. PhD Dissertation. University of Florida.

Fournier, S. (1998). Consumers and their brands: developing relationship theory in consumer research. Journal of Consumer Research, 24, 343-373.

Fournier, S. (2001). Building brand community on the HarleyDavidson posse ride. Harvard Business School Note No. 5-501052 (pp. 1-20). Boston: Harvard Business School.

Geuens, M., Weijters, B., \& De Wulf, K. (2009). A new measure of brand personality. International Journal of Research in Marketing, 26, 97-107.

Goldberg, L. R. (1990). An alternative "description of personality": the big-five factor structure. Journal of Personality and Social Psychology, 59, 1216-1229.

Greenwald, A. G. (1968). Cognitive learning, cognitive response to persuasion, and attitude change. In A. G. Greenwald, T. C. Brock, \& T. M. Ostrom (Eds.), Psychological foundations of attitudes. New York: Academic.

Grohmann, B. (2009). Gender dimensions of brand personality. Journal of Marketing Research, 46, 105-119.

Hamilton, D. L. (1979). A cognitive-attributional analysis of stereotyping. In L. Berkowitz (Ed.), Advances in experimental social psychology (pp. 53-84). New York: Academic.
Hamilton, D. L. (1981). Cognitive representations of persons. Social Cognition: The Ontario Symposium (pp. 135-160). Hillsdale: Erlbaum.

Hendricks, W. A., \& Robey, K. W. (1936). The sampling distribution of the coefficient of variation. The Annals of Mathematical Statistics, 7, 129-132.

Hovland, C. I., \& Weiss, W. (1951). The influence of source credibility on communication effectiveness. Public Opinion Quarterly, 15, 635-650.

$\mathrm{Hu}$, L., \& Bentler, P. M. (1999). Cutoff criteria for fit indexes in covariance structure analysis: conventional criteria versus new alternatives. Structural Equation Modeling, 6, 1-55.

Interbrand. (2006). Best global brands: 2006 ranking. http://www. interbrand.com/best_global_brands.aspx?year $=2006 \&$ langid $=1003$

Jacoby, J., \& Chestnut, R. (1978). Brand loyalty measurement and management. New York: Wiley.

Janiszewski, C. (1998). The influence of display characteristics on visual exploratory search behavior. Journal of Consumer Research, 25, 290-301.

Jaworski, B. J., \& Kohli, A. K. (1993). Market orientation: antecedents and consequences. Journal of Marketing, 57, 53-70.

Johnson, K. E., \& Mervis, C. B. (1997). Effects of varying levels of expertise on the basic level of categorization. Journal of Experimental Psychology: General, 126, 248-277.

Kang, Y.-S., \& Herr, P. M. (2006). Beauty and the beholder: toward an integrative model of communication source effects. Journal of Consumer Research, 33, 123-130.

Katz, E. (1957). The two step flow of communication: an up-to-date report of a hypothesis. The Public Opinion Quarterly, 21, 61-78.

Katz, D. (1960). The functional approach to the study of attitudes. The Public Opinion Quarterly, 24, 163-204.

Keller, K. L. (1993). Conceptualizing, measuring and managing customer-based brand equity. Journal of Marketing, 57, 1-22.

Kelley, H. H. (1967). Attribution theory in social psychology. In D. Levine (Ed.), Nebraska symposium on motivation (pp. 192-238). Lincoln: University of Nebraska Press.

Kelley, H. H. (1972). Attribution in social interaction. In E. E. Jones, D. E. Kanhouse, H. H. Kelley, R. E. Nisbett, S. Valins, \& B. Weiner (Eds.), Attribution: Perceiving the causes of behavior (pp. 1-26). Morristown: General Learning.

Kirmani, A. (1990). The effect of perceived advertising costs on brand perceptions. Journal of Consumer Research, 17, 160-171.

Kohli, A. K., \& Jaworski, B. J. (1990). Market orientation: the construct, research propositions, and managerial implications. Journal of Marketing, 54, 1-18.

Kunda, Z. (1990). The case for motivated reasoning. Psychological Bulletin, 108, 480-498.

Lasswell, H. D. (1948). The structure and function of communication in society. In L. Bryson (Ed.), The communication of ideas (pp. 37-51). New York: Harper.

Lumpkin, G. T., \& Dess, G. G. (1995). Simplicity as a strategy-making process: the effects of stage of organizational development and environment on performance. Academy of Management Journal, 38, 1386-1407.

MacInnis, D. J., \& Jaworski, B. J. (1989). Information processing from advertisements: Toward an integrative framework. Journal of Marketing, 53, 1-23.

MacInnis, D. J., Moorman, Ch, \& Jaworski, B. J. (1991). Enhancing and measuring consumers' motivation, opportunity, and ability to process brand information from ads. Journal of Marketing, 55, 32-53.

MacKenzie, S. B., \& Lutz, R. J. (1989). An empirical examination of the structural antecedents of attitude toward the ad in an advertising pretesting context. Journal of Marketing, 53, 4865.

Mervis, C. B., \& Rosch, E. (1981). Categorization of natural objects. Annual Review of Psychology, 32, 89-115. 
Meyers-Levy, J. (1991). Elaborating on elaboration: the distinction between relational and item-specific elaboration. Journal of Consumer Research, 18, 358-367.

Meyers-Levy, J., \& Peracchio, L. A. (1995). Understanding the effects of color: how the correspondence between available and required resources affects attitudes. Journal of Consumer Research, 22, 121-138.

Meyvis, T., \& Janiszewski, C. (2004). When are broader brands stronger brands? An accessibility perspective on the success of brand extensions. Journal of Consumer Research, 31, 346-357.

Mintzberg, H. (1978). Patterns in strategy formation. Management Science, 24, 934-948.

Mitchell, A. A. (1979). Involvement: A potentially important mediator of consumer behavior. In W. Wilkie (Ed.), Advances in consumer research (pp. 191-196). Ann Arbor: Association for Consumer Research.

Netemeyer, R. G., Krishnan, B., Pullig, C., Wang, G., Yagci, M., Dean, D., et al. (2004). Developing and validating measures of facets of customer-based brand equity. Journal of Business Research, 57, 209-224.

Noble, C. H., \& Mokwa, M. P. (1999). Implementing marketing strategies: developing and testing a managerial theory. Journal of Marketing, 63, 57-73.

Nunnally, J. C. (1978). Psychometric theory. New York: McGraw-Hill.

Obermiller, C., \& Spangenberg, E. R. (1998). Development of a scale to measure consumer skepticism toward advertising. Journal of Consumer Psychology, 7, 159-177.

Oliver, R. L. (1999). Whence consumer loyalty? Journal of Marketing, 63, 33-44

Park, C. W., \& Young, S. M. (1986). Consumer response to television commercials: the impact of involvement and background music on brand attitude formation. Journal of Marketing Research, 23, 11-24.

Park, C. W., Jaworski, B. J., \& MacInnis, D. J. (1986). Strategic brand concept-image management. Journal of Marketing, 50, 135-145.

Park, C. W., Milberg, S., \& Lawson, R. (1991). Evaluation of brand extensions: the role of product feature similarity and brand concept consistency. Journal of Consumer Research, 18, 185-193.

Park, H., Arndt, J., \& Reder, L. M. (2006). A contextual interference account of distinctiveness effects in recognition. Memory \& Cognition, 34, 743-751.

Petty, R. E., \& Cacioppo, J. T. (1986). Communication and persuasion: central and peripheral routes to attitude change. New York: Springer

Petty, R. E., Cacioppo, J. T., \& Schumann, D. (1983). Central and peripheral routes to advertising effectiveness: the moderating role of involvement. Journal of Consumer Research, 10, 135-146.

Piercy, N. F. (1998). Marketing implementation: the implications of marketing paradigm weakness for the strategy execution process. Journal of the Academy of Marketing Science, 26, 222-236.

Plummer, J. T. (1984/1985). How personality makes a difference. Journal of Advertising Research, 24, 27-31.

Putrevu, S., \& Lord, K. R. (1994). Comparative and noncomparative advertising: attitudinal effects under cognitive and affective involvement conditions. Journal of Advertising, 23, 77-91.

Ragas, M. W., \& Bueno, R. J. (2002). The power of cult branding: How 9 magnetic brands turned customers into loyal followers (and yours can, too!). New York: Crown Business.

Richins, M. L., \& Bloch, P. H. (1986). After the new wears off: the temporal context of product involvement. Journal of Consumer Research, 13, 280-285.
Richins, M. L., Bloch, P. H., \& McQuarrie, E. F. (1992). How enduring and situational involvement combine to create involvement responses. Journal of Consumer Psychology, 1, 143-153.

Riegner, C. (2007). Word of mouth on the web: the impact of Web 2.0 on consumer purchase decisions. Journal of Advertising Research, 47, 436-447.

Ries, A., \& Ries, L. (2002). The 22 immutable laws of branding. New York: Harper Collins.

Rosch, E. (1975). Cognitive reference points. Cognitive Psychology, 1, $532-547$.

Rosch, E. (1978). Principles of categorization. In E. Rosch \& B. Lloyd (Eds.), Cognition and categorization (pp. 27-47). Hillsdale: Erlbaum.

Rota, L. M., \& Zellner, D. A. (2007). The categorization effect in hedonic contrast: Experts differ from novices. Psychonomic Bulletin \& Review, 14, 179-183.

Shannon, C. E., \& Weaver, W. (1949). The mathematical theory of communication. Urbana: University of Illinois Press.

Smallman, R., \& Roese, N. J. (2008). Preference invites categorization. Psychological Science, 19, 1228-1232.

Song, X. M., \& Parry, M. E. (1997). A cross-national comparative study of new product development processes: Japan and the United States. Journal of Marketing, 61, 1-18.

Srivastava, R. K., Fahey, L., \& Christensen, H. K. (2001). The resourcebased view and marketing: the role of market-based assets in gaining competitive advantage. Journal of Management, 27, 777-802.

Stayman, D. M., Alden, D. L., \& Smith, K. H. (1992). Some effects of schematic processing on consumer expectations and disconfirmation judgments. Journal of Consumer Research, 19 , 240-255.

Sternthal, B., Phillips, L. W., \& Dholakia, R. (1978). The persuasive effect of source credibility: a situational analysis. Public Opinion Quarterly, 42, 285-314.

Sung, Y., \& Kim, J. (2010). Effects of brand personality on brand trust and brand affect. Psychology \& Marketing, 27, 639-661.

Swasy, J. L., \& Munch, J. M. (1985). Examining the target of receiver elaborations: rhetorical question effects on source processing and persuasion. Journal of Consumer Research, 11, 877-886.

Taylor, S. E., Fiske, S. T., Etcoff, N. L., \& Ruderman, A. J. (1978). Categorical and contextual bases of person memory and stereotyping. Journal of Personality and Social Psychology, 36, 778-793.

Triplett, T. (1994). Brand personality must be managed or it will assume a life of its own. Marketing News, 28, 9.

Ülkümen, G., Chakravarti, A., \& Morwitz, V. G. (2010). Categories create mind-sets: the effect of exposure to broad versus narrow categorizations on subsequent, unrelated decisions. Journal of Marketing Research, 47, 659-671.

Van Trijp, H. C. M., Hoyer, W. D., \& Inman, J. J. (1996). Why switch? Product category-level explanations for true varietyseeking behavior. Journal of Marketing Research, 33, 281-292.

Venable, B. T., Rose, G. M., Bush, V. D., \& Gilbert, F. W. (2005). The role of brand personality in charitable giving: an assessment and validation. Journal of the Academy of Marketing Science, 33, 295-312.

Wentzel, D. (2009). The effect of employee behavior on brand personality impressions and brand attitudes. Journal of the Academy of Marketing Science, 37, 359-374.

Zaichkowsky, J. L. (1985). Measuring the involvement construct. Journal of Consumer Research, 12, 341-352. 